\title{
WindSHIELD WASHERS, GUTTER PUNKS, ROMA, ROBBERY, AND GRAFFITI: WHAT IS INSECURITY IN ITALY TODAY?
}

\author{
Laura Sartori
}

A foreigner robbed, beat up, raped, and dumped an Italian woman, Francesca Reggiani, to die in a ditch as she was returning home along a poorly lit, scruffy road in Tor di Quinto, a peripheral area of Rome and the site of a gypsy camp. This incident in 2007 was the final straw that resulted in an explosive debate on safety and security in Italy, coinciding with the presentation by the government of its Security Package on 30 October.

Looking back over the year, the press reported a number of similar incidents. On 23 September, a 25-year-old Romanian woman was raped in full daylight, as was a 40-year-old Italian nurse on the steps of the church in Spresiano (Treviso). In Bologna, but also in Milan and other large cities, a solidarity march was organized after the latest act of violence against a woman, which took place in the Giardini Margherita in the city center. In Gorgo al Monticano (Treviso), a couple, custodians of a villa, were tortured and killed. The same had happened to another couple in an area of Brescia in the spring. On 6 March, during a robbery at a tobacconist's shop in Magnago (Milan), the 75-year-old owner was beaten up and her daughter was raped by a group of four immigrants. Another tobacconist was robbed and killed in Turin on 7 May while on the way to making a bank deposit. The same happened in Naples on 8 October. On 15 November, in a residential area of Milan,

Notes for this chapter begin on page 251 . 
a well-known doctor died after being tied up, along with his son, by four people attempting to burgle the house during the night.

In the Rome underground, a girl from Borgata Fidene died as a result of a wound to her eye after two Romanian girls stuck an umbrella into it. Again in Rome, a film director and a journalist-Giuseppe Tornatore and Lamberto Sposini-were attacked and robbed with no apparent motive other than theft and aggression. In the first months of the year, Naples was at the center of national and international press interest due to the "emergency" of the rubbish that lay rotting and uncollected in the streets. In March, an art exhibition of graffiti (titled "Street Art") in Milan offered the opportunity for a discussion on whether graffiti should be considered artwork or vandalism. It was then revealed that the sums paid by local councils (e.g., Rome and Bologna) for removing graffiti from building facades are extremely high. In the municipality of Chiavari, the mayor has decided that the owners of the buildings affected should pay for the costs of the cleaning themselves. In the same period there were the first incidents relating to windshield washers (the subject had already been tackled in Bologna in the spring of 2005) and beggars, culminating in the order signed in Florence at the end of August that prohibits windshield washers from plying their trade at traffic lights for any length of time.

This resulted in an acrimonious debate about the ideas and politics of the left wing. A large number of center-left mayors have been involved in bitter arguments about their approach to security. At the forefront is the "sheriff-mayor" of Bologna, Sergio Cofferati, and his loud calls for "legality." Interventions that spring to mind are the removal of the Roma shacks along the Reno River and the signing of several orders to tackle urban decline (e.g., the anti-loitering order and the prohibition on selling off-license alcohol after 9:00 PM in the evening). In the summer of 2006, after the construction of a wall that was aimed at impeding drug peddling and assisting police operations in Via Anelli in Padua, the mayor, Flavio Zanonato, decided to fine the clients of prostitutes and send notifications about the fines to their relatives at home. At the beginning of July, the mayor of Rimini, Alberto Ravaioli, declared war on the street traders who invade the beaches to sell their wares. The mayor of Turin, Sergio Chiamparino, was criticized for cleaning up the "junkies park" on the banks of the Stura River, in the same way in which complaints were made about the chairman of the Provincial Council of Milan, Filippo Penati, and his approach to the management of Roma camps and clandestine immigrants. On 14 April, a traffic warden slapped a fine on a car for parking illegally in Via Sarpi in the heart of Milan's Chinatown, and the entire Chinese community protested, creating problems of public disorder for an entire day. This 
incident permitted the center-right mayor, Letizia Moratti, to attract and channel attention toward the question of security.

Discussions on (in)security, commonplace among citizens, have become the daily bread of the mass media, and the topic is now a burning issue at institutional levels for the police, mayors, political parties, and government. However, there is an easily identifiable and fundamental defect that clouds the terms of this discussion. Disorder and urban decline, crime (both organized and common), and a sense of insecurity represent three dimensions that should not be confused, if such a delicate subject is to be tackled without the influence of ideologies and prejudice.

\section{What Are We Talking About?}

Above all, there should be clarity about one thing: when talking about a sense of (in)security, there is a tendency to confuse personal fear of crime with concern about crime. Personal fear refers to the anxiety generated by the possibility of becoming a victim of crime-that is, being mugged, attacked, robbed, or raped. Concern with crime, on the other hand, relates to a less personal emotion linked to the spread of crime in the place in which one lives (one's own municipality, province, region, or country). The former deals with the individual context of the subject and with the perceived risk of a danger that may be only potential. The latter relates to a more generalized concern about a changing and threatened social and political order and, for this reason, depends greatly on individual values.

It is important to keep these two dimensions distinct as they are not necessarily interlinked and are measured by different indicators and explained by specific factors. In effect, they are distributed unevenly throughout the population on the basis of socio-demographic characteristics and geographic area. We will now concentrate on personal fear because this aspect more greatly affects the social construction of the "security problem" that has been the focus of attention in public debates.

The facts set out above can be traced to two types of event that are usually related to the population's sense of insecurity and an acceptance of the idea of personal fear. On the one hand, there are real crimes-those established by the law-such as robbery, sexual assault, murder, bag-snatching, and pickpocketing. On the other hand, there are those matters considered to be "signs of disorder" that are typically associated with urban decline, such as vandalism, derelict buildings, beggars, drunks, gutter punks, prostitutes, drug peddlers, and overflowing or burned rubbish bins. Crimes and signs of disorder 
are invoked in an attempt to explain where the sense of (in)security of the "wo/man in the street" comes from. Yet there are other important aspects to be taken into consideration.

Primarily, there is the context of the occurrence. In a large city, phenomena such as urban decline, criminality, and, as a result, (in)security may be more widespread and less tolerated by the resident population. There may be areas characterized by drug peddling and the presence of prostitutes, or there may be squares and parks in a state of abandonment that have become populated by petty criminals. It is no coincidence that the metropolitan cities have been the first to demand the drawing up of Security Pacts. Other contexts, possibly more peripheral and isolated, tend to experience criminal acts such as house burglaries. Cities may offer greater "opportunities" for carrying out crimes (bag-snatching, pickpocketing, theft) and may represent the most suitable site for behavior that infringes on established social schemata, away from informal societal controls.

Another relevant circumstance is immigration. Cutting across the phenomena of crime and urban decline, this more general theme may greatly affect the perception of security. Beginning in the 1980s and 1990s, data highlight the increase in foreigners of some nationalities among the total number of persons accused of committing crimes. This partially foreseeable trend is linked to the higher percentage of foreigners in relation to the population as a whole. The increase in immigrants as perpetrators of crimes is not, however, homogeneous in relation to the crimes committed: the data go from 70 percent of foreigners accused of pickpocketing to 51 percent accused of robbery or theft in houses to 3 percent accused of bank robberies. ${ }^{1}$ Attached to the actual data there is a complex process of the social construction of the migration phenomenon. According to some, it is those individuals with a greater tendency to flout societal rules who join the illegal elements of immigration, the "bad" elements toward whom normal citizens may show signs of intolerance. According to others, a negative reading of the figure of the immigrant-above all, if illegal, male, young, and belonging to particular nationalities - as an individual more likely to adopt deviant behavior and to violate common behavioral rules depends on the difficult and adverse conditions (including prohibitive migration policies and inclusion in circles of society limited to the illegal market) found in the host country.

A third relevant aspect in an analysis of the relationship between urban decline, crime, and insecurity pertains to the mass media. The role that newspapers, television, and other sources of information play in organizing the public debate and in defining and establishing agendas-and, therefore, the priorities for the representation of news-can 
have a considerable effect on public discourse, both between citizens and between institutions. In this regard, there is talk of "agenda setting," which highlights the capacity of the media both to structure and to define the importance of news items, to include or exclude determinate subjects, and to form judgments in a more or less veiled manner. The mass media, therefore, has a role in the construction and diffusion of a number of social stereotypes and representations, and, above all, can forcefully contribute to the generation of "social alarm." It is in relation to this issue that the theme of immigration becomes intertwined with how events are presented when they have a foreigner as their focus. The "states of emergency" concerning the rubbish, the Roma, the windshield washers, and the immigrants have been present for many years and "emerge" on a cyclical basis to dominate the public debate. The centrality of these subjects is also evidenced by the initiatives of journalists and their publications, which dedicate special editions or reports to them. Such is the case of the Corriere della Sera's "camper," which travels around Milan, observing and describing situations of urban decline, minor criminality, and citizens' reactions.

Racketeering constitutes the last aspect of those matters discussed in this chapter that contribute to the sense of (in)security. In defining the overall picture, it is helpful to emphasize the fact that we will not be referring here to organized crime as such. Nonetheless, some phenomena of urban decline and common criminality (such as pickpocketing) can be linked to racketeering and exploitation circuits that, in some instances, can be traced back to organized crime. An example of this is the rubbish in Naples. Rotting and uncollected trash constitutes a classic sign of disorder and urban decline that can contribute to making citizens feel less secure but that reveals, at its source, management by a criminal organization. Windshield washers and beggars at street corners can be the visible signs of an exploitation network. In October, a report made by Italian police officers, in collaboration with Interpol in Bucharest, shed light on the racket managing the "market of the cripples": mutilated and disabled invalids were "bought" in hospitals by clans of Eastern European gypsies and sent to the pavements of Italy, Spain, and France. However, there is nothing much new here if we recall the "entrepreneur" Peachum organizing the beggars in Bertolt Brecht's The Threepenny Opera.

To conclude, then, what we are actually talking about has three distinct components: urban decline, crime, and the safety of citizens. The first two contribute, in differing degrees, to the increasing sense of insecurity among the population. To these elements are added more layers - the city, immigration, the mass media, racketeering - that help us better understand the phenomenon 


\section{But How Are Things Really?}

The subject of security is frequently reduced merely to talking about crime and formulating the equation "increase in crimes = increase in insecurity." The data tell us, on the other hand, that this idea only partially captures a much more complex situation.

\section{Personal Fear and Crime}

Above all, it is impossible to lump everything together and refer to crime as a uniform phenomenon. Different types of criminality continually change their spatial and temporal status. If bag-snatching diminishes throughout all of the regions, including the southern regions where they have always been highest, there is a growth in house burglaries and pickpocketing in the northern regions.

In Italy, as in both the United States and France, it is acceptable to hypothesize that the fear of suffering a crime began to flourish in the 1970s, when there was a consistent growth in robberies, hold-ups, and murders. In effect, house burglaries, pickpocketing, and bag-snatching increased between 1984 and 1991. Subsequently, bag-snatching has tended to diminish and continues to do so, while thefts and pickpocketing have first diminished, then increased, and then diminished again (see figure 11.1). In 2006, the rate of burglaries was 240.4 for every 100,000 inhabitants, compared to 401.6 in 1996. Nonetheless, this type of crime is very attractive to the media, and every now and then it is "rediscovered," especially when it can be linked to immigrants. Such is the case with the small, semi-organized groups specializing in theft-frequently accompanied by violence and murder-who "spread terror" in the countryside of the wealthy northeast. ${ }^{2}$

Despite the decrease in certain crimes, the percentage of persons demonstrating a distinguishable level of fear has remained the same. Table 11.1 shows a quota of around 30 percent of Italian families who fear that they might become the victims of crime, with some geographic differences, between the years 1993 and 2006. Generally speaking, an increase in personal fear can be observed in the northeast, which became apparent only in the 1990s and which has remained at the same level since 2000. Nevertheless, this increase is still lower, not only than the national average (as at the beginning of the 1990s), but also than that of other geographic areas, with the exception of the islands.

This fact confirms neither a generalized increase in personal fear, as some sensationalist stories and populist feelings would have it, nor a decrease, which might be conceivable if the fear depended more on 


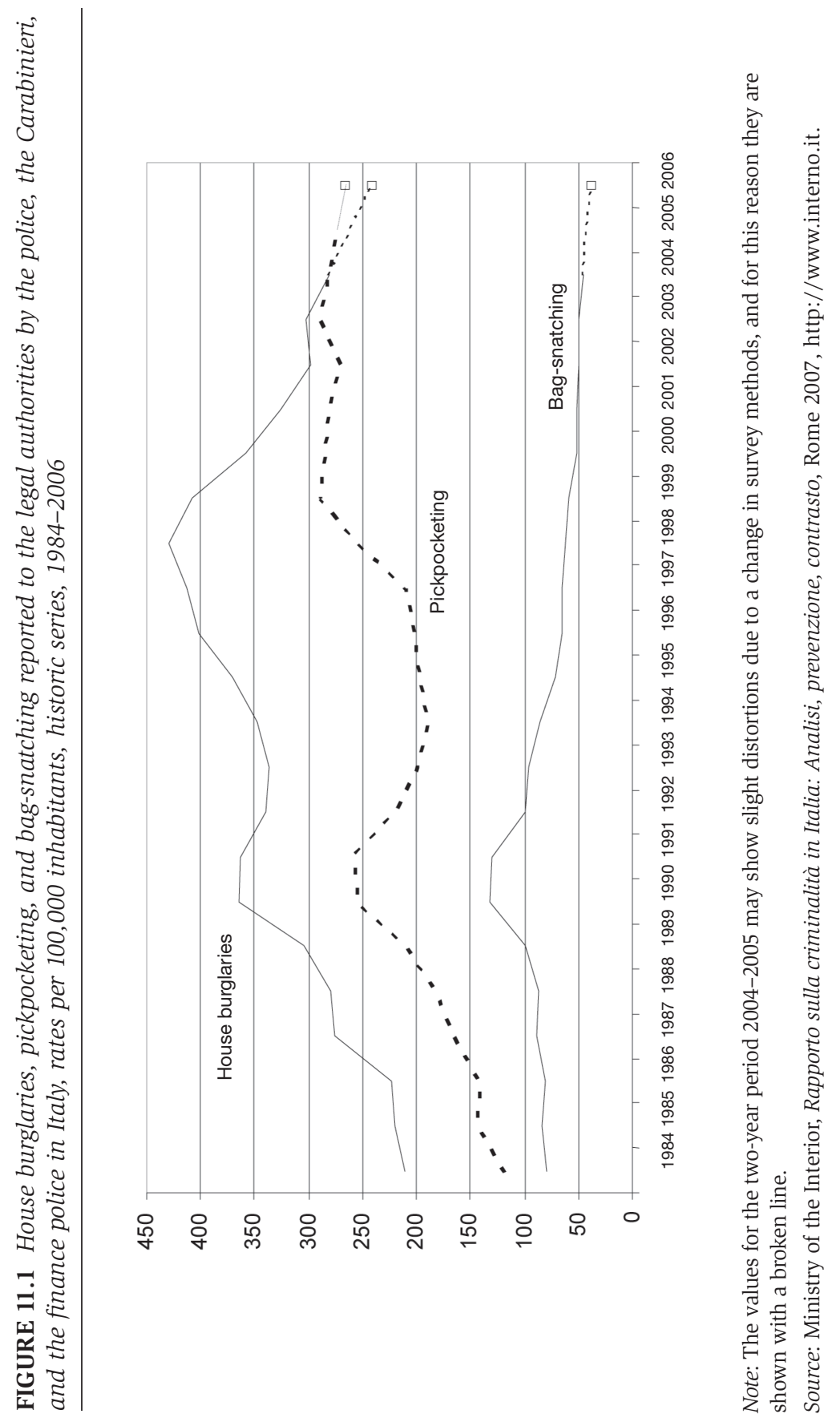


TABLE 11.1 Families who consider the area in which they live as very or relatively at risk of crime, according to the area of the country per 100 families in that area, 1993-2005

\begin{tabular}{lcccccc}
\hline & Northwest & Northeast & Center & South & Islands & Italy \\
\hline 1993 & 34.8 & 17.3 & 31.1 & 38.3 & 31.0 & 31.2 \\
1994 & 33.2 & 17.8 & 32.4 & 37.0 & 31.4 & 30.8 \\
1995 & 32.7 & 19.6 & 32.7 & 38.8 & 26.2 & 30.9 \\
1996 & 34.1 & 17.5 & 29.6 & 33.5 & 28.2 & 29.3 \\
1997 & 32.9 & 21.7 & 29.4 & 34.2 & 23.3 & 29.3 \\
1998 & 34.7 & 25.9 & 29.1 & 35.1 & 26.4 & 31.1 \\
1999 & 34.7 & 27.9 & 34.0 & 35.5 & 26.2 & 32.5 \\
2000 & 33.6 & 28.7 & 31.4 & 31.9 & 22.1 & 30.6 \\
2001 & 33.3 & 27.8 & 31.2 & 33.4 & 23.7 & 30.8 \\
2002 & 31.9 & 26.8 & 30.5 & 29.5 & 22.9 & 29.2 \\
2003 & 29.4 & 23.6 & 27.4 & 30.9 & 21.9 & 27.4 \\
2005 & 30.3 & 28.1 & 27.7 & 33.7 & 21.6 & 29.2 \\
2006 & 33.1 & 28.0 & 35.2 & 38.2 & 23.4 & 32.7 \\
\hline
\end{tabular}

Note: In 2004, no surveys were carried out.

Source: ISTAT data elaboration, Aspetti della vita quotidiana, annual survey.

the frequency than the seriousness of the crime. An increase in thefts or pickpocketing in one's own city has a greater effect on the subjective perception of the risk of being a victim of crime than does a murder, however vicious. The recent crimes of Erba and Perugia ${ }^{3}$ affect the collective imagination and can have negative consequences in terms of social relationships and the level of trust in others. However, they have less impact on feelings of personal fear.

There appears, however, to be a more profound process at work-a progressive transformation of the widespread fear of being a victim of crime into a concern about crime that changes and threatens the social and political order (i.e., the second dimension of the sense of insecurity). A more general and abstract sense of uneasiness is emerging with regard to the system of values practiced by individuals and the societies to which they belong. It is to this dimension that the more transversal subjects listed above-immigration in particular-are connected and on which they can be brought into play, contributing to the construction and elaboration of the "security issue." The most recently available data appear to support this hypothesis: between 2005 and 2007, the number of respondents claiming to be worried about crime rose from 33.8 percent to 44.2 percent. ${ }^{4}$ 


\section{Personal Fear and Urban and Social Decline}

Crime is not sufficient to explain the citizens' sense of insecurity. "Urban decline" is a phenomenon that must be examined in order to gain a better understanding of personal fear. All of the signs of disorder and uncivilized behavior that characterize an area or a city represent the cracks in the moral and social order of collective society. The observation of drug peddling, street prostitution, beggars, drunks, gutter punks participating in fights (between gangs or immigrants), and the prolonged "hanging out" of young people, students, or drop-outs in the squares during the day or at night with music, drugs, or alcohol-all of this brings to mind social disorder. Rubbish overflowing in bins, derelict buildings covered with slogans and graffiti, unusable telephone boxes, broken street lamps, and crumbling roads are, on the other hand, indications of a material disorder. These signs should not be underestimated: while the former suggest a violation of the accepted norms of behavior, the latter indicate a lack of care for collectively owned assets and a lack of control on the part of the authorities.

A letter dated 24 July 2007 from a family in Bologna provides evidence of how incidents of physical and social decline can cause the collapse of those daily points of reference that allow people to move about the city with confidence:

Two Saturdays ago, together with a couple of friends, we took our 6-yearolds to watch a Pippi Longstockings show in the Montagnola Park that started at 9:30 PM. Just crossing the park was troubling due to the population occupying it. Then, at around 11:00 PM, at the end of the evening, we found ourselves in the midst of a scene worthy of the Bronx. A northern African was on the ground being violently kicked by a fellow national, while other ugly low-lifers then appeared out of the dark and began to beat each other up, throwing full beer cans at each other. Throughout all this, I, my wife, my son, and his two little friends who were with us didn't know where to run to get out of their way and to avoid being hit by the beer cans, while the children were screaming in terror at the scene of such unprecedented violence happening before our very eyes. ${ }^{5}$

There is no doubt that crossing through some of the larger cities (Tor di Quinto in Rome, Porta Palazzo in Turin, Piazza Verdi in Bologna, Via Anelli in Padua, the Spanish quarters in Naples, the historic centers of Genoa and Bari) can make people feel uneasy. These areas have become symbolically "non-places," neither public nor private, where new methods of social and institutional control are required. Overall, urban decline-typically in the larger cities-is interpreted as a symptom of the collapse of social order, in part because it nurtures a 
lack of confidence in others and impedes social networks. It is furthermore taken as a glaring example of the detachment of the authorities and of their incapacity to control and resolve critical issues. In sum, urban decline, in its social and physical connotations, influences personal fear even more than crimes. ${ }^{6}$

\section{How Do Citizens and Authorities React at the Local and National Levels?}

Citizens and authorities-at both the local and national levels-are those who experience, suffer, endure, and tackle the situations relating to crime and urban decline. But in what way?

\section{The Local Level}

Citizens must judge for themselves the risks of being a victim of crime and the signs of disorder in their local areas and cities. Undoubtedly, the perception of insecurity in daily existence depends on both socialdemographic characteristics and context. However, it is unlikely that people will declare themselves to have been the victims of a crime or will note urban decline without any well-founded reason.

Citizens can react to fear both as individuals and collectively. On an individual level, a first reaction is that of "protecting" oneself, one's family, and one's assets. There are typical safety measures for the home, such as the installation of reinforced doors, window bars, and alarms. Individuals can take out home insurance policies to protect against theft or can even change residences if (as a result of victimization or urban decline) the situation becomes intolerable. ${ }^{7}$ Another method of protecting oneself is by getting a weapon, a classic subject of attention that is "exposed" by the mass media in relation to citizens' fear. However, despite what the media would lead us to believe, it is inaccurate to claim that there has been a "rush" of the Italian population to arm itself. Based on police statistics, the number of authorizations for gun licenses has declined consistently since 1997: over the past 10 years, authorizations have decreased from 52,243 to around 34,000. There are now 58 gun licenses for every 100,000 inhabitants, compared to 90 licenses in 1997. It might be thought that the prefectures have actively limited the number of annual authorizations, but what effectively matters is that the number of requests has been in decline, given that the difference been requests and effective authorizations is negligible. ${ }^{8}$ Periodically, following incidents such as that in Guidonia-where, on 4 November, an ex-army officer, in a 
state of depression, shot and killed two people-there is talk of implementing more stringent controls in order to evaluate and monitor more frequently the psychological state of those holding licenses. On 7 November, a government bill to this effect was put forward. ${ }^{9}$

This may be an example of an institutional response to citizens' fear. However, it is certainly not the first time that this has happened; it is part of the category of symbolic and, at times, populist responses with which such subjects are tackled. It is sufficient to recall the proposal by Melchiorre Cirami, a member of Parliament, who in 2002 proposed to recognize the right of all citizens to self-defense and sovereignty, at least in their own homes, during the full "emergency" period of the attacks on villas in the Veneto area. The possession and use of a weapon to promote a sense of security and to deter criminals can have tragic consequences when used, above all, by those who are inexpert. However, at times, the desired effect may be achieved. In mid-October, for example, a group of bandits was chased off, without injury, by the explosion of 10 shots fired by a Filipino manservant in the villa of the jeweler Eugenio Sinopoli (the brother of orchestra conductor Giuseppe Sinopoli) in the province of Padua.

A third defense strategy that citizens may adopt relates to changing individual lifestyles. One may decide not to use public transport when traveling or not to move about on one's own or not to travel on roads or through areas frequented by those responsible for urban decline. Women more frequently put this kind of behavior into practice, especially in the larger cities. One may also come to the extreme decision to avoid leaving the house at all (this applies particularly to the elderly) or to change one's area of residence.

Citizens may also highlight situations of danger and urban decline in open letters addressed to the police, the local authorities (typically the mayor), and the newspapers. This option opens the way for collective reactions. The strategy usually followed is that of forming groups and associations whose objective is to resolve local instances of decline. The examples are many, the most common being that of citizen committees for security in an area or in a city as a whole. These groups organize day- and nighttime activities to combat the sense of abandonment and to encourage residents to "take back" social control in specified areas. There is an attempt to revive conditions of livability and societal rules in places where the social and moral order has been undermined and broken down by deviant behavior. In the immediate periphery of Milan, for example, residents have decided to make use of the park in the area in order not to "leave it in the hands of urban decline and small groups of criminals." In doing so, they are acknowledging the fact that collective action plays a fundamental role 
in reintegrating resources of trust that form the basis of common rules of cohabitation.

If taken on board by local authorities, these initiatives may have positive consequences. This has been the case with the anti-noise and anti-loitering orders made by the council in Bologna in 2003 and the dismantling of the Roma camps in Rome. ${ }^{10}$ Similarly, in Padua, the committee for the ghetto, an area behind the two central market squares, managed to bring to the attention of the authorities the situation of disorder caused by the summer ritual of the spritz aperitif. ${ }^{11}$ From 7:00 PM until late in the evening, the squares and surrounding narrow streets used to be filled with young people drinking aperitifs, disturbing the residents, and leaving behind a veritable carpet of plastic cups. The "aperitif area" was moved for the summer of 2007 to the university area of Portello, and this change was accompanied by two reactions: the ghetto inhabitants were relieved and satisfied by the result, while those in the Portello area began to protest. The former then began to complain that in the summer months the squares had become a "desert," frequented only by gutter punks and other downand-outs. The same thing happened in Turin, where, in the summer, the inhabitants of the Murazzi complained that this had become the main area for summer events and the aperitif ritual, which attracted down-and-outs, a few drug pushers, students, and "normal" people. Equally, in Milan, in the areas of the Navigli and Corso Como, there is a similar sort of problem.

Undoubtedly, local council administrations are faced with the problem of how to manage collective rituals-such as those of the aperitif or night life in general-which may have consequences in terms of physical disorder (broken glass, trash, noise) for the residents and which may be interlinked with signs of social disorder. Nonetheless, what Bologna and Padua have in common, and what sets them apart from other, even larger cities, is their role as university cities. In these historic centers, the universities have a deeply rooted presence. As a consequence, there is a tendency to a form of concentration of activity rather than dispersion over the territory, and this affects aspects of the management and regulation of the urban space. In cities such as Florence, Turin, and Milan, the situation with regard to these activities appears to be more separate, almost segregated, and there seems to be a specialization taking place: in different squares, drugs are peddled, people have an aperitif, and Filipinos, Romanians, Moldavians, and university students meet in their spare time.

The "Bus Stop Angels" initiative is an example of a concrete response on the part of a number of individuals to the problems of security. A theatre group, the department for the city council's security 
policies, the council's public relations office, and the public transport company in Bologna support the presence of easily identifiable volunteers (wearing angel wings), who are provided with civic assistant and council identity cards. Between 9:30 PM and 12:30 AM, these volunteers accompany anyone at the bus stops who requests this service. When, on the other hand, citizens' voices are not heard, there may be even stronger feelings of resignation and anger that result in independent actions toward self-organization. Following the 2006 murder of a woman in the center of Genoa, a group of citizens formed a safety committee aimed at making the subject of safety and security the focus of a public debate and sought to bring this to the attention of various institutions. After more than a year of waiting on both the mayor and the interior minister, the committee chairman unburdened himself to the Corriere della Sera on 3 November. Another example comes from Bologna, where, in order to improve poor street lighting, which encouraged drug peddling and loitering, the Orgeonica association, after the lack of response from the city council on the subject, in July managed to obtain sponsorship from the Beghelli company for the installation of new lights under the arcades.

Another form of self-organization is that of local patrols. Following a murder in Rome on 31 October, the media turned its attention again to the existence of citizens' patrols. However, some incidents, which occurred after the surge of emotional reaction in the city and were organized by right-wing militants, should be defined as violent and xenophobic acts of aggression rather than patrols. These events were strongly condemned by both the right (with the exception of some in the ranks of the Northern League) and the left. For some years, on the other hand, there has been talk of the "Padanian patrols," organized by the Northern League in the regions of the North. In particular, those in the Veneto province of Treviso, under the guiding hand of the "sheriff-mayor" Giancarlo Gentilini, have been called out by the media. ${ }^{12}$ More generally, the purpose of the patrols is that of "keeping watch" over some areas that have been "taken away" from the informal control of citizens. In some cases, the patrols either supplement or even replace formal police control.

The citizens' relationship with the police is twofold: it is an important point of reference, but it also an easy target for criticism and polemics. A sense of insecurity depends not only on the risk of being a victim of crime but also on being "alone" when faced with a situation of danger. To the scarcity of neighborly relationships, the lack of trust in others, and a low level of social integration should be added the feeling of being abandoned by the police, who will not intervene, are too few, and do not "control" the territory. One of the most common 
complaints of citizens is that "you never see a policeman here and, even less, when you need one." Although highly criticized, the figure of the local policeman is the authorities' response to the need of the populace to feel itself more "protected."

In interpreting the phenomenon of patrols, it is possible to identify typically Weberian motivations for the actions taken. These may be the result of an emotional group response to a $\left(\mathrm{n}^{\text {th }}\right.$ ) serious incident (affectively determined action). They may derive from a demagogic action supported by political parties and extremist organizations (rational action in relation to value). Or they may be a rational response of the affected community in terms of efficiency and speed in relation to the response of the authorities (rational action in relation to purpose).

Citizens' strategies to combat a sense of insecurity, therefore, may consist of an exit strategy, with individuals becoming resigned in the face of a situation held to be unchangeable (expressed by moving away, no longer going out, or losing faith in neighbors and the authorities), or a voice strategy, with citizens making their voices heard. Yet it appears that there is a double process at work. On the one hand, there are individual, emotional solutions without the mediation of the appropriate authorities (since these are inefficient and trust in them has been undermined), which consist of personal responses to collective problems, according to the ideas of Bauman, Beck, and Giddens about the progressive isolation of the individual. On the other, there are collective responses to these collective problems. Building from below, these organizational processes are the tools available to the community for the recovery and renewal of a public asset such as security. Despite the more general trend toward the privatization of services (including that of security), ${ }^{13}$ citizens continue to make requests to political figures: first to local mayors and then to national authorities.

It has already been shown how mayors may respond to citizens' concerns at a local level with decrees that regulate the sale and consumption of alcohol, loitering, noise, the closure of venues, and urban decorum. They may also dust off and enforce existing regulations from the criminal code of the 1930s that prohibit and punish actions such as painting on walls and buildings-the modern graffiti. There may be a reorganization by the police and the municipal community police of the presence of officers in the troublesome "hot spots." There may also be specific initiatives in collaboration with local associations for the protection of women or for the regeneration of urban areas. In some cases, this signifies the initiation and regulation of new phenomena, while in others it indicates the adaptation and contextualization of existing norms. 


\section{The National Level}

Security and public order are not, however, matters that are the responsibility of mayors, and they may well direct their requests for assistance to the national level. But in what way? In the spring of 2007, several mayors organized public protests after events linked to the issue of security were reported by the news. This was the case in Milan, where the mayor, Letizia Moratti, accompanied by colleagues and other social elements (retailers and associations), took to the streets on 27 March to draw attention to the problems of security. On the same day, there was also a march of area committees requesting that the mayor and public authorities work together on these issues.

Thus, in May, a dialogue was initiated between the mayors and the home secretary, Giuliano Amato, which has led to the signing of various Security Pacts. ${ }^{14}$ Within an agreement framework signed by the association of Italian municipalities (ANCI) and the home secretary, the cities of Naples, Trieste, Rome, Milan, Turin, Catania, Cagliari, Genoa, Bari, Bologna, Venice, Modena, Florence, and Prato have all signed Security Pacts. This measure aims to be a tool for a form of solidarity between the state and local authorities in the effort to combat crime and urban decline. It provides for more funds to local area police and community support officers, suited to the requirements of each city, in relation to security, the Roma question, anti-forgery operations, unauthorized retailing, and the fight against prostitution and organized begging.

On 31 October, the Security Package was presented, comprising five bills of law that were the fruit, not only of the development and acceptance of the requests advanced in the preceding months, but also of an expanded planning approach on the part of the government. The package relates to the possibility of intervening on the subject of security and public order, serious crimes and the certainty of the penalty, the Prüm Treaty (which involves cross-border cooperation in combating terrorism and illegal immigration), and the fight against organized crime. A number of modifications to the text were presented on 19 December, and on 28 December, the security decree was approved.

The events at Tor di Quinto sharpened the debate that this package had generated. There had been criticism from the opposition but also heavy attacks from the radical wing of the current center-left government. ${ }^{15}$ The problem of security is, in fact, a delicate subject about which the left-and not only the Italian left-has conflicting sentiments that run along basic ideological cleavages. Furthermore, the issue of security has been irreparably linked to problems of immigration and has been exploited in the political battles between the left and the right. ${ }^{16}$ 


\section{Conclusions: Crime, the Law, and the Left}

We can try to reconstruct the positions of traditionally left-wing intellectuals and politicians with regard to crime. In effect, as Anthony Giddens claims, "it is not right wing to admit that crime and social disorder represent a serious problem for many citizens." 17 Research informs us that, under equal conditions, workers, retailers, and artisans, together with those who possess little or no education, are more afraid than other professional figures. ${ }^{18}$ As a result, traditionally leftleaning sources of support suffer in relation to this issue. This is evidenced by the numerous letters from citizens on the topic of safety, an example of which can be found in Corrado Augias's column in $\mathrm{La}$ Repubblica of 7 November: "I am a left-wing voter who is disappointed in Rossana Rossandra's declarations about the dismantlement of illegal camps. She said these were fascist approaches! Words worthy of a left wing incapable of facing up to reality!... Caught between the near criminal arrogance of a certain kind of right wing and the pronouncements of this left, it is the safety of the citizen that is the weakest."

Even left-wing intellectuals and journalists lament the false problem of security (and the consequences of immigration) and oppose opening up the reformist and progressive wing of the Italian left. The case of the windshield washers, which exploded following the decree in Florence, is an eloquent example of this division. From Turin to Venice, Viareggio to Merano and Naples, there are mayors and other elements of the center-left who attempt to "regulate" the newly emerging situations-such as illegal parking attendants but also tourists who drop litter and travel around the art cities in scanty clothing-which, in some cases, have violent overtones.

These are all examples of behavior that influences the feeling of a rift in-if not the breaking down of-order and decorum, and that, over time, exasperates the populace. On the other hand, the decree signed by the mayor of Cittadella (Padua), Massimo Bitonci, on 17 November, relating to citizens' range of actions with regard to public order and the responsibilities of the state, opens up the path to easy ideological manipulation. ${ }^{19}$ In effect, with these new regulations, the mayors can adopt emergency measures to safeguard public safety and urban security, in collaboration with the prefectures.

Public opinion is witness to a number of different positions. For example, the historian Marco Revelli condemns the trend to regulate and command respect for social order from on high. He talks of the "despotism of reality" motivating the new left-wing approach, which tends to remove, even if only symbolically, the threat represented by those in the lowest levels of society and their "disposable lives." Holding similar views is 
Fausto Bertinotti, who prefers an attack on the "highest"-the guilty parties directing the crime rackets-rather than the "lowest." Even the ministers Paolo Ferrero, Rosy Bindi, and Clemente Mastella agree on the need to integrate rather than criminalize the "poorest of the poor" as a way of combating the street rackets. As pointed out by La Stampa, Barbara Spinelli hopes for a rejection of policies that exclude the "lowest," recalling that there have been other cases in Europe similar to that of the windshield washers: Filippo Neri defending the gypsies in 1500 from Pope Pius V, who wanted to chase them out of Rome because of their lack of faith, and the socialist battles of the workers and artisans in the nineteenth century. The non-exclusion of these groups has contributed to the construction of Europe, even if at considerable cost. As the historian Franco Cardini recalls in La Stampa: "A serious policy of inclusion means losing consensus."

Undoubtedly, fear should not be exploited in order to win easy support-a claim that is made against the "political party of the mayors." Yet it is necessary to acknowledge that talking about and tackling the question of security does not necessarily conflict with modern leftwing culture. Sociologist Carlo Trigilia, in the pages of Il Sole 24 Ore, highlights a "sort of legal relativism by which those who carry out an action are of more importance than the legality of the action in question." Catholic-based solidarity would lead us to think that helping the lowest automatically produces collective benefits. However, a perverse effect may be obtained: taking action to protect specifically the most disadvantaged could diminish the capacity to reduce overall inequality and to promote social cohesion.

Toleration of behavioral disorders-which influences the perception of decline, contributes to fissures in the network of neighborhood relationships, and leads to diminishing trust-does not help to make citizens safer and/or more integrated. The mayors (many from the left) are attempting to interpret and respond to the demands of their citizens from all the political parties. Nevertheless, the actions that they have taken do not appear to comply with the more instinctive and "gut" responses of the communities. They appear rather to be a concrete attempt to embed and embody those security policies that fall, at least in part, into the category of symbolic politics. This type of politics identifies the end-users to whom it offers a symbolic asset and for whom it has great significance. The enjoyment of this asset, as Alessandro Pizzorno states, ${ }^{20}$ is possible in conditions of "intersubjective acknowledgment," that is, in circumstances of a shared collective identity. For this reason, it is essential to work with models of political socialization when analyzing the mechanisms of loyalty and lifestyles with regard to networks of social relationships. 
This is why the rifts in the social and moral order that characterize the life of a neighborhood or a city are perceived as important signs of insecurity and should not be ignored-as they are by many mayors. However, these models of political socialization and social appurtenances change, and the political culture to which they are linked must be capable of perceiving such changes. This is important, above all, because security is a public asset with a strongly symbolic dimension that nonetheless has a real impact on the daily life of social actors. Thus, there is also a need for the regulation of public policies.

As Luciano Violante stated several years ago, the widespread minor crimes that affect millions of citizens should be pursued just as vigorously as the more serious crimes. ${ }^{21}$ Giuliano Amato referred to the same thing on 30 August in the Corriere della Sera in relation to the mayor of New York City, Rudolph Giuliani, and his 360-degree fight against crime in the 1990s. Giuliani managed to improve his citizens' quality of life by reducing crime in the city-first, by targeting the less important types of illegality, such as not paying for tickets on the subway or drinking in the streets. ${ }^{22}$ Reducing these symbols of disorder contributed to lowering the level of crime in many neighborhoods, as did the physical presence of policemen and -women, who are the bearers of a message of reassurance to the inhabitants. The disorder that makes citizens insecure also covers other forms of illegality (extortion, illegal employment, etc.), which must similarly be tackled. This vision reminds us of the words of the United Kingdom's prime minister, Tony Blair, who fought effectively not only against crime but also against the root causes of crime: "Tough on crime, tough on the causes of crime." ${ }^{23}$

\section{Notes}

1. Ministry of the Interior, Rapporto sulla criminalità in Italia: Analisi, prevenzione, contrasto, Rome 2007, http://www.interno.it.

2. Here, the local administrations led by the Northern League exploit the facts and the residents' fear, but then work effectively on the issues of integration. I. Diamanti and N. Porcellato, "Sorpresa nel Nordest l'integrazione funziona," Limes, no. 4 (2007): 47-62.

3. In Erba, a couple murdered a neighbor, her child, and another couple of neighbors because "they were too noisy." In Perugia, an English student was murdered.

4. Periodic survey, June 2007, of the Social Capital Observatory carried out by Demos-Coop, which is run by Ilvo Diamanti. For further information, see http://www.agenziamedialab.com.

5. La Repubblica (Bologna edition), 24 July 2007. 
6. M. Barbagli, ed., Rapporto sulla criminalità in Italia (Bologna: Il Mulino, 2003).

7. According to ISTAT data of 2006, in the northern regions, home insurance against theft is taken out by 20 percent of families, compared to 9 percent in the center of Italy and 3 percent in the south and the islands.

8. Barbagli, Rapporto sulla criminalità.

9. Consideration should be given to the difference between a license to carry a gun and one to keep a gun in the house. In the first instance, there is a requirement to make a request and to have a medical visit every year. In the second situation, once the authorization has been obtained, it is permanent.

10. This happened even before the murder of Francesca Reggiani on 31 October. See, for example, the work of the neighborhood committee Cinest, in Rome, which culminated in a demonstration on 27 October.

11. The spritz is a typical aperitif from the Veneto area made with Prosecco and either Aperol or Campari.

12. The epithet "sheriff-mayor" was specifically tailored to Gentilini, the Northern League mayor of Treviso, due to his extremist and racist statements. The expression was subsequently applied to Cofferati, the mayor of Bologna, on a completely different basis when, in 2005, he tackled for the first time the subject of windshield washers at traffic lights and linked it to questions of legality.

13. There is talk of privatizing both the demand (with citizens no longer turning to the state but personally paying for these services) and the supply (with private companies providing security in place of the state).

14. See http://www.interno.it/mininterno/site/it/temi/sicurezza/sottotema010.html.

15. Romano Prodi had won in the last elections and led a center-left coalition as prime minister from April 2006 to January 2008.

16. The data confirm only one well-known fact: the subjects of security and public order are traditionally associated with the cultural heritage and politics of the right. In recent polls, 39.8 percent of the populace believe that a center-right government is more capable of resolving the problems relating to crime, and 34.5 percent believe that a center-right government can better address the issues relating to immigration. See http://www.agenziamedialab.com.

17. A. Giddens, La Repubblica, 29 August 2006.

18. It is well-known that in Italy personal fear is more widespread in the lower levels of society-even if the risk of being a victim of crime is higher among the upper echelons-while social preoccupation with crime pertains to the more conservative classes.

19. Minimum requirements-income, housing, status as a non-threat to societyhave been established for immigrants who wish to reside in the municipality. This decree was welcomed with joy by the Northern League, while generating arguments from the left and the center.

20. A. Pizzorno, "Sulla razionalità della scelta democratica," Stato e mercato 7, no. 1 (1983): 3-46.

21. L. Violante, “Apologia dell'ordine pubblico,” Micromega 4 (1995): 124-140.

22. F. E. Zimring, The Great American Crime Decline (Oxford: Oxford University Press, 2006), 272.

23. This expression was used in his first speech as shadow home secretary during the Labour Party conference in 1992. 